\title{
Learning Strategies at SD Muhammadiyah 2 Tulangan during the Covid 19 Pandemic [Strategi Pembelajaran SD Muhammadiyah 2 Tulangan Saat Pandemi Covid 19]
}

\author{
Lintang Nimas Primaningtyas*, Muhlasin Amrullah \\ \{ lintangnimas2903@gmail.com, muhlasin1@umsida.ac.id\} \\ Fakultas Psikologi dan Ilmu Pendidikan, Universitas Muhammadiyah Sidoarjo, Indonesia
}

\begin{abstract}
The study aims to analyze the learning process in the (online) network, supportive factors and teacher inhibitory factors in carrying out online learning during the covid-19 pandemic. The study was carried out at muhammadiyah elementary school 2 the estimated shidoarjo city of sidoarjo in April. The study USES descriptive qualitative methods. The subject used in this study was an elementary school teacher at 2 tulangan elementary elementary school. The data-collection techniques used in this study include interviews, documentation and field notes. The result of this study is that the covid-19 pandemic has hada profound impact on the learning process, learning that is normally executed directly is now being transferred to online learning. Learners are bored and bored during learning. Online education done for primary-age children is less effective. A number of teacher factors in the online learning process are the availability of cell phones, quotas and a steady Internet network. In addition to supporting factors in online learning, there are several teacher inhibitors in online learning. These inhibiting factors include the fact that they are still at the elementary school level, so only a few students have cellphones, therefore this can make learning ineffective. Through online there are also obstacles that occur for teachers, namely many students who deliberately do not participate in online learning because they do not have an internet quota to access learning so that students are left behind. And there is also a learning strategy carried out by SD Muhammadiyah 2 Tulangan. On the other hand, face-to-face online learning through applications is the most beneficial thing to break the spread of Covid-19 and maintain the mental health of teachers and students from exposure to the Covid-19 virus.
\end{abstract}

Keywords: Online Learning, Inhibiting Factors, Learning Strategies

\begin{abstract}
Abstrak. Penelitian ini bertujuan untuk menganalisis proses pembelajaran dalam jaringan (daring), faktor-faktor pendukung serta faktor-faktor penghambat guru dalam melaksanakan pembelajaran daring di masa pandemi COVID-19. Penelitian ini dilaksanakan di SD Muhammadiyah 2 Tulangan Kota Sidoarjo yang terhitung pada bulan April. Penelitian ini menggunakan jenis penelitian metode kualitatif deskriptif. Subjek yang digunakan dalam penelitian ini adalah guru sekolah dasar di SD Muhammadiyah 2 Tulangan. Teknik pengumpulan data yang digunakan dalam penelitian ini berupa wawancara, dokumentasi dan catatan lapangan. Hasil dari penelitian ini adalah pandemi COVID-19 membawa dampak yang sangat besar terhadap proses pembelajaran, pembelajaran yang biasanya dilaksanakan secara langsung kini dialihkan menjadi pembelajaran daring. Peserta didik merasa jenuh dan bosan selama melaksanakan pembelajaran. Pembelajaran daring yang dilakukan untuk anak usia sekolah dasar dirasa kurang efektif. Ada beberapa faktor pendukung guru dalam proses pembelajaran daring
\end{abstract}


yaitu ketersediannya handphone, kuota dan jaringan internet yang stabil. Selain adanya faktor yang mendukung dalam pembelajaran daring terdapat juga beberapa faktor penghambat guru dalam pembelajaran daring. Faktor penghambat tersebut diantaranya adalah karena masih di jenjang sekolah dasar jadi hanya beberapa siswa yang memiliki handphone oleh sebab itu hal tersebut dapat menjadikan pembelajaran yang tidak efektif. Melalui daring juga terdapat adanya hambatan yang terjadi bagi guru yaitu banyak siswa yang sengaja tidak mengikuti pembelajaran daring disebabkan tidak memiliki kuota internet untuk mengakses pembelajaran sehingga siswa tersebut tertinggal. Dan juga terdapat stategi pembelajaran yang dilakukan oleh SD Muhammadiyah 2 Tulangan. Di sisi lain Pembelajaran daring dengan tatap muka melalui aplikasi menjadi hal yang paling menguntungkan guna memutus penyebaran Covid-19 serta menjaga kesehatan keselamatan jiwa guru dan siswa dari terpaparnya virus Covid-19.

Kata Kunci: Pembelajaran Daring, Faktor Penghambat, Strategi Pembelajaran

\section{Pendahuluan}

Akibat dari pandemi Covid-19 membuat pemerintah mengeluarkan kebijakan baru demi menghentikan pemencaran Covid-19 yaitu mengimplementasikan ajakan masyarakat untuk melaksanakan Physical Distancing atau memberi jarak dengan orang lain sejauh satu meter dan menghindari kerumunan dan berbagai acara pertemuan yang menimbulkan perkumpulan (Covid-19, 2020). Selain itu pemerintah menerapkan kebijakan untuk Dirumah Saja seperti kerja dirumah atau Work From Home (WFH) dan kegiatan apapun yang berhubungan dengan perkumpulan atau pertemuan ditiadakan dan diganti dengan media online. Pada kondisi seperti ini semua guru atau tenaga pendidik diharuskan untuk mengganti pembelajaran menggunakan E-learning atau melalui media online. Berbagai platform digunakan untuk melakukan pengajaran sehingga perlu didukung dengan fasilitas pembelajaran yang baik dan pemanfaatan teknologi informasi. Seluruh siswa diwajibkan untuk menggunakan alat komunikasi seperti Handphone dengan bijak untuk mendukung proses pembelajaran. Pembelajaran daring dengan tatap muka melalui aplikasi menjadi hal yang paling menguntungkan guna memutus penyebaran Covid-19 serta menjaga kesehatan keselamatan jiwa guru dan siswa dari terpaparnya virus Covid-19.[1]

Namun banyak sisi negatif dari pembelajaran daring yaitu adanya hambatan ini terjadi bagi guru yaitu banyak siswa yang sengaja tidak mengikuti pembelajaran daring disebabkan tidak memiliki kuota internet untuk mengakses pembelajaran sehingga siswa tersebut tertinggal dan tidak mendapatkan nilai selain itu masiha ada beberapa siswa yang tidak memiliki fasilitas seperti handphone untuk melakukan kegiatan pembelajaran. Hal ini membuat guru menjadi bimbang dalam memberikan nilai dan kebijakan karena masih banyak kendala yang belum dapat diselesaikan, sedangkan hambatan bagi seorang siswa yaitu pembelajaran yang sulit untuk dipahami karena pembelajaran daring siswa dituntut untuk mencari lebih luas ilmu pelajaran. Sedangkan belajar dirumah tidak menjamin siswa untuk belajar karena terkadang siswa asik dengan kegiatan dirumah sehingga lupa untuk ikut pembelajaran daring. Pembelajaran daring menjadi pembelajaran yang kurang efektif apabila masih banyak terdapat hambatan- hambatan yang terdapat pada guru dan siswa. Penulis tertarik untuk melakukan penelitian ini disebabkan pembelajaran daring sedang berlangsung dan dapat ditinjau secara langsung dengan mengetahui pembelajaran daring menurut persfektif guru dan siswa dan mengetahui seberapa efektif pembelajaran daring. 


\section{Metode Penelitian}

Penelitian ini menggunakan metode penelitian kualitatif deskriptif. Pendekatan kualitatif merupakan proses penelitian untuk memahami masalah-masalah sosial atau manusia dengan menganalisis kata-kata untuk menciptakan gambaran kompleks dan menyeluruh, serta melaporkan pandangan informasi terperinci yang diperoleh dari para sumber informasi dalam lingkungan alami. Pendekatan kualitatif juga bertujuan untuk menyelidiki, menemukan, menggambarkan, serta menjelaskan kualitas atau keistimewaan dari pengaruh sosial yang tidak dapat dijelaskan, diukur, atau digambarkan melalui pendekatan kuantitatif. Teknik pengambilan data dalam penelitian ini melalui wawancara, dokumentasi dan observasi, adapun trianggulasi yang di pakai dalam penelitian ini adalah trianggulasi teknik. Penggunaan metode kualitatif ini dimaksudkan untuk memperoleh gambaran mengenai Strategi SD Muhammadiyah 2 Tulangan dalam pembelajaran di Tengah Pandemic Covid 19.

\section{Hasil dan Pembahasan}

\subsection{Sejarah Berdirinya Sekolah Dasar Muhammadiyah 8 Tulangan}

Awal mulanya dulu belum bernama SD Muhammadiyah 2 tetapi namanya SDIT atau Sekolah Dasar Islam Terpadu pertama di tahun 2006. Dan SDIT ini sendiri murni berdiri karena gagasan ranting amal usaha Muhammadiyah, terdapat inisiasi dari beberapa orang ranting termasuk disitu ada bapak Agus, bapak Yanto (almarhum), bapak Yani (almarhum), dan ada beberapa orang yang msih berkomitmen untuk mengurus SDIT ini dan pertama kali lokasinya berada di Jl. Raya Kemantren No. 2, keputran, kemantren, Kec. Tulangan, kabupaten Sidoarjo, Jawa Timur. Itu adalah gedung pertama dibangun dan dulu jumlah siswanya masih ada 9 orang siswa, kemudian makin hari makin bertambah-bertambah, dan di tahun pertama 1 lokal, tahun kedua masih 1 lokal juga, dan baru tahun berikutnya bertambah sampai detik ini.[2]

Untuk struktural karena kondisi siswa pada saat itu sangat sedikit jadi pengurusnya diambil yang pnting-penting saja seperti kepala sekolah, guru ada dua, TU ada satu. Dan juga belum ada bendahara, baru di tahun kedua sudah mulai lengkap strukturalnya hingga di tahun ini sudah mulai sangat lengkap yaitu adanya guru karyawan yang jumlahnya seratus. Di SD Muhammadiyah 2 terdapat pembedaan level pengajarannya yaitu ada guru regular, guru ngaji berjumlah dua puluh dua orang, kebutuhan khusus, kemudian TU komisi umum berjumlah enam orang. Dan hingga pada akhirnyaSekolah Muhammadiyah pada tahun 2008 itu mengikrarkan diri menjadi sekolah kreatif, indukannya berada di Barata Jaya. Guna mengadopsi konsep-konsep pembelajaran yang sangat humanity anak-anak didik tidak terlalu dikekang dengan peraturan-peraturan yang terikat contohnya berseragam begitupun guruya, SD Muhammadiyah 2 tetap memiliki seragam tetapi tidak baku harus memakainya di hari tertentu yang penting bebas santai tapi tetap sopan pakai baju busana muslim. Hari senin selasa pakai baju putih, rabu kamis HW dan batik, dan di hari jum'at bebas. Gurunya lebih bebas dan jarang menggunkan seragam, kecuali moment-moment tertentu yang diharuskan memakai seragam baru dipakai. Pada hari hari nasional juga tidak memakai seperti hari batik juga tidak memakai dan tidak terpaku dengan konsep seperti itu karena patokannya itu saat pembelajaran seperti Gebyar budaya Jawa mereka mewajibkan guru-guru nya pakai adat jawa kebaya, surjan untuk laki-laki dan lebih ke karakter lingkungan.

\subsection{Proses Pembelajaran SD Muhammadiyah 2 selama Pandemi}


Berdasarkan hasil penelitian yang didapat dari wawancara yang dilakukan dengan tatap muka langsung dengan narasumber. Adapun hasil penelitian yang diperoleh dalam penelitian ini yaitu disat pandemi seperti ini semua sekolah mengharuskan kita PJJ atau Pembelajaran Jarak Jauh. Dan banyak orang yang salah paham tentang PJJ itu sendiri dan PJJ juga tidak selalu harus dalam jaringan jika jaringan identiknya dengan online, dalam jaringan belum tentu tatap online jadi walaupun masih dalam jaringan tetapi kita tidak selalu tatap online jadi tuntas di hari itu, dan tidak selalu selesai. Jdi tahapan di dalam online juga msih ada spek-spek nya, PJJ itu tidk hrus selalu dlm jaringan, melainkan PJJ itu pembelajaran dimana jarak jauh dari kondisi real di awal. Dan untuk masa pandemi ini jawaban online tidak bisa menjadi jawaban ataupun solusi.

Proses pembelajaran di SD Muhammadiyah 2 Tulangan juga telah menggunaakan daring tatap online seperti vc di whatsapp, zoom, google meet. Semua sudah dilakukan tetapi banyak permasalahan dari para siswa dan siswi yang muncul pertama kali SD Muhammadiyah ideal menggunakan goggle classroom jadi ada batas timer pengerjaan, semakin kesini menjadi beban tersendiri untuk para siswa. Dan akhirnya SD Muhammadiyah 2 Tulangan mengubahnya menjadi metode blended learning tetapi tetap menggunakan google classroom sebagai tugas untuk mendata KBM dan feedback-nya SD Muhammadiyah 2 Tulangan memakai paper dan dikumpulkan setiap hari sabtu dan yang mengumpulkan orang tuanya. Keberhasilannya menggunakan metode ini yaitu berkisar $80 \%$. Dan PJJ nya masuk kedalam kebijakan yang sifatnya classical atau kebijakan regional, penguasaan terhadap proses juga dilakukan dan prosesnya itu terdapat dinastatik, motorik, sosial, ketuhanan.

\subsection{Faktor Penghambat Pembelajaran selama Daring}

Faktor yang menghambat dalam proses pembelajaran daring adalah pertama belum semua peserta didik memiliki handphone pribadi, peserta didik yang hanya memiliki handphone pribadi hanya sedikit apalagi masih berada di Sekolah Dasar sisanya belum memiliki handphone sendiri atau handphone gabung dengan orang tuanya sehingga harus menunggu orang tua nya pulang kerja. Dan juga banyak yang tidak mempunyai handphone jadi tidak dapat mengikuti pembelajaran. Faktor yang kedua adalah peserta didik yang malas meskipun peserta didik tersebut memiliki handphone sendiri atau tidak sesuai dengan aturan yang ditetapkan, misalnya guru memberikan tugas dari jam 08.30 tiba-tiba peserta didik mengirimkan atau mengumpulkan tugas tersebut tidak tahu jam berapa kadang sampai malam atau melewati batas waktu pengumpulan tugas yang diberikan dan mengganggap remeh tugas atau juga sering banyak orang tua nya yang mengerjakan tugas anaknya dan anaknya sediri tidak mempedulikannya dan asik bermain sehingga tidak ada materi yang masuk di otaknya. Faktor yang ketiga adalah banyak orang yang belum terlalu paham dengan teknologi atau bisa disebut dengan gaptek yaitu gagap teknologi hal ini yang sangat penghambat pembelajaran karena masyarakat belum terbiasa dengan teknologi yang semakin hari semakin maju apalagi hal ini juga ditekankan utuk masyarakat kalangan bawah karena keterbatasan handphone juga mempersulitnya. Faktor keempat adalah materi yang tidak tuntas saat pembelajaran daring dilakukan. [3]

Berbeda halnya dengan pembelajaran yang dilakukan secara langsung, misalnya pemberian tugas pada saat pembelajaran daring peserta didik hanya berkutat disatu tugas saja tidak bergerak ke tugas selanjutnya hal tersebut menjadikan guru sulit berpindah ke materi pembelajaran yang berikutnya karena belum selesai semuanya. Sementara itu siswa dan siswi pada saat pandemi seperti ini sangat membutuhkan handphone android dan kuota internet yang 
cukup, pulsa harus ada, kuota harus penuh. Karena jika terkendala oleh kuota membuatpusing. Karena pembelajarannya menggunakan sambungan internet.

\subsection{Strategi Pembelajaran saat pandemi}

Langkah-langkah menyusun strategi pendidikan di saat pandemi Covid-19 yaitu : 1) Melakukan peninjauan kembali terhadap target pembelajaran yang ingin dicapai, agar secara rasional selaras dengan situasi dan kondisi baru dalam new normal. 2) Identifikasi sumber daya yang perlu dimiliki dan diadakan agar tujuan baru yang telah ditetapkan tersebut dapat dicapai dengan ketersediaan sumber daya yang ada. 3) Petakan situasi dan kondisi masing-masing guru dan siswa yang harus bersiap-siap melakukan model pembelajaran baru berbasis blended learning sebagaimana dirancang. 4) Kajilah gap antara kebutuhan dan ketersediaan untuk menyusun langkah-langkah strategis dan operasional yang perlu segera dilakukan untuk menjembataninya. 5) Eksekusi langkah-langkah tersebut secara kreatif dan inovatif dengan menjalin berbagai kemitraan dengan pihak-pihak eksternal yang peduli mengenai pendidikan.

Strategi yang dilakukan SD Muhammadiyah 2 Tulangan yaitu dengan melakukan metode blended learning tetapi tetap menggunakan google classroom sebagai tugas untuk mendata KBM dan feedback-nya SD Muhammadiyah 2 Tulangan memakai paper dan dikumpulkan setiap hari sabtu dan yang mengumpulkan orang tuanya. Keberhasilannya menggunakan metode blended learning yaitu berkisar 80\%. Dan di SD Muhammadiyah 2 Tulangan juga melakukan eksekusi langkah-langkah tersebut secara kreatif dan inovatif dengan menjalin berbagai kemitraan dengan pihak-pihak eksternal..

\section{Kesimpulan}

Berdasarkan hasil penelitian yang telah dilakukan dengan metode kualitatif melalui teknik pengumpulan data berupa wawancara yang telah dilakukan pada salah satu guru di SD Muhammadiyah 2 Tulangan. Pandemi COVID- 19 sangat membawa dampak yang signifikan dalam dunia pendidikan, terutama dalam proses pembelajaran yang dilaksanakan oleh guru. Proses pembelajaran yang dilaksanakan guru berubah yang biasanya pembelajaran dilaksanakan secara langsung menjadi pembelajaran dalam jaringan (daring). Pembelajaran daring dirasa kurang efektif bagi guru terutama untuk anak usia sekolah dasar, karena pembelajaran dilaksanakan secara daring maka guru juga kurang merasa maksimal dalam memberikan materi pembelajaran sehingga menjadikan materi tidak tuntas dan terdapat hambatan yang dirasakan guru dalam pembelajaran, hambatan tersebut diantaranya adalah belum semua peserta didik memiliki handphone dan masih banyak orang tua yang sibuk bekerja. Orang tua menjadi seseorang yang sangat penting dalam pelaksanaan pembelajaran daring, karena orang tua secara yang secara langsung terlibat dalam membimbing dan mengawasi peserta didik dalam pembelajaran. Pemberian motivasi menjadi sangat berarti bagi peserta didik, hal tersebut dilakukan agar peserta didik kembali semangat meskipun belajar dari rumah.

\section{Ucapan Terima Kasih}

Dengan terselesaikannya Artikel Karya Ilmiah ini penulis mengucapkan terima kasih yang sedalam dalamnya kepada Allah S.W.T atas limpahan karunia dan hidayahnya sehingga penulis dapat melaksanakan penelitian dan menyelesaikan Artikel Karya Ilmiah. Teman-teman kelompok kami yang saling membantu dan mendukung dalam mengerjakan Artikel Karya 
Ilmiah ini dan atas kerjasamanya. Para Narasumber yang sudah memberikan informasi sehingga penulis dapat melaksanakan penelitian dan menyelesaikan Artikel Karya Ilmiah.

\section{References}

[1] Luh Devi Herliandry, "Pembelajaran Pada Masa Pandemi Covid-19," Jurnal Teknologi Pendidikan, vol 22. No. 1, tahun. [2020]. Available : http://journal.unj.ac.id/unj/index.php/jtp/ar ticle/view/15286

[2] Ayu Wulandari, Gusti Ngr Sastra Agustika, "Dramatik Pembelajaran Daring Pada Masa Pandemi Covid-19, “ Mimbar PGSD Undiksha, vol 8. No. 3, tahun.[2020]. Available : https://ejournal.undiksha.ac.id/index.php/JJPG SD/article/view/29259

[3] Firdaus Firdaus, "IMPLEMENTASI DAN HAMBATAN PADA PEMBELAJARAN DARING DI MASA PANDEMI COVID 19,” Jurnal Kependidikan, vol. 6, no. 2, tahun. [2020]. Available : https://jurnal.ummi.ac.id/index.php/JUT/articl e/view/1009 